\title{
PENGEMBANGAN MODUL KEWIRAUSAHAAN BERORIENTASI PENGEMBANGAN EKONOMI WILAYAH PESISIR BENGKULU UNTUK MAHASISWA PGSD UNIVERSITAS BENGKULU
}

\author{
Panut Setiono $^{1}$, Dwi Anggraini ${ }^{2}$, Pebrian Tarmizi ${ }^{3}$ \\ ${ }^{1,2,3}$ PGSD FKIP Universitas Bengkulu \\ ${ }^{1}$ setiono.pgsd@unib.ac.id
}

\begin{abstract}
Learning entrepreneurship in tertiary institutions by utilizing regional potential as a source of learning material is one of the efforts to increase student interest in learning entrepreneurship. Given that Bengkulu province is a coastal area rich in natural resources and ecosystem diversity that can be utilized for economic development for local communities. However, the current source of entrepreneurship learning materials only contains general material and has not brought students closer to the regional potential in their area. The purpose of this study is to determine the development of the material presented in the module and to test the feasibility of an economic developmentoriented module for the coastal areas of Bengkulu to be used in entrepreneurship learning in the Elementary School Teacher Education Program, Bengkulu University. The method used in this research is research and development $(R \& D)$. The research and development model used was the modified Borg \& Gall model. The development steps taken include (1) preliminary studies, (2) planning, (3) product development, (4) product validation, (5) product testing, and (6) final products. The subjects of this study were material experts and educational technology experts. The product trials conducted involved 40 students who were taking entrepreneurship courses in the even semester of the 2019/2020 academic year. The results showed that the entrepreneurship module oriented to the economic development of the coastal areas of Bengkulu had gone through product feasibility testing at the expert validation test stage, small group trials, and field trials. From the results of the trials that have been carried out, it can be concluded that the entrepreneurship module developed is feasible to use.
\end{abstract}

Keywords: entrepreneurship; coastal economy; module

\begin{abstract}
Abstrak
Pembelajaran kewirausahaan di perguruan tinggi dengan memanfaatkan potensi wilayah sebagai sumber materi pembelajaran merupakan salah satu upaya untuk meningkatkan minat mahasiswa untuk belajar kewirausahaan. Mengingat provinsi Bengkulu merupakan daerah pesisir yang kaya dengan keragaman sumber daya alam dan ekosistem yang dapat dimanfaatkan untuk tujuan pengembangan ekonomi masyarakat lokal. Tetapi, sumber materi pembelajaran kewirausahaan saat ini hanya berisi materi yang bersifat umum dan belum mendekatkan mahasiswa pada potensi wilayah di daerahnya. Tujuan penelitian ini yaitu untuk mengetahui pengembangan materi yang disajikan dalam modul dan menguji kelayakan modul berorientasi pengembangan ekonomi wilayah pesisir Bengkulu untuk digunakan dalam pembelajaran pada mata kuliah kewirausahaan mahasiswa Prodi Pendidikan Guru Sekolah Dasar Universitas Bengkulu. Metode yang digunakan dalam penelitian ini adalah reseach and delevelopment (R\&D). Model penelitian dan pengembangan yang digunakan yaitu model Borg \& Gall yang dimodifikasi. Adapun langkah-langkah pengembangan yang dilakukan antara lain: (1) studi pendahuluan, (2) perencanaan, (3) pengembangan produk, (4) validasi produk, (5) uji coba produk, dan (6) produk akhir. Subjek penelitian ini adalah ahli materi dan ahli teknologi pendidikan. Ujicoba produk yang dilakukan melibatkan 40 orang mahasiswa yang sedang mengambil mata kuliah kewirausahaan pada semester Genap Tahun Ajaran 2019/2020. Hasil penelitian menunjukkan bahwa modul kewirausahaan berorientasi pengembangan ekonomi wilayah pesisir Bengkulu telah melalui uji kelayakan produk pada tahap uji validasi ahli, uji coba kelompok kecil, serta uji coba lapangan. Dari hasil uji coba yang telah dilakukan dapat disimpulkan bahwa modul kewirausahaan yang dikembangkan layak untuk digunakan.
\end{abstract}

Kata Kunci: kewirausahaan; modul; pesisir ekonomi

\begin{tabular}{llll}
\hline Received & $: 2020-11-01$ & Approved & $: 2021-01-14$ \\
Reviesed & $: 2021-01-05$ & Published & $: 2021-01-31$ \\
\hline
\end{tabular}


Jurnal Cakrawala Pendas is licensed under a Creative Commons AttributionShareAlike 4.0 International License.

\section{Pendahuluan}

Wilayah pesisir merupakan suatu wilayah pertemuan antara daratan dan lautan yang menghasilkan suatu aktivitas manusia di darat dan dilaut yang saling bersinergi memberikan dampak sosial ekonomi pada wilayah darat (Pramono \& Sulistyarso, 2013). Berbagai aktivitas ekonomi dapat dilakukan oleh masyarakat dalam mengelola dan memanfaatkan wilayah pesisir untuk meningkatkan kesejahteraannya. Untuk itu diperlukan upaya pengembangan ekonomi berbasis lokal secara sinergis antara pemerintah daerah serta masyarakat sekitar dalam menciptakan sebuah lapangan pekerjaan baru dan meransang pertumbuhan ekonomi di daerah tersebut (Leigh \& Blakely, 2016).

Pengembangan wilayah dapat dilakukan melalui pengelompokkan suatu wilayah berdasarkan potensi lokal yang dimiliki berdasarkan unggulan sektornya (Safitri et al., 2018). Pengelompokkan ini dapat menjadi penentu kebijakan untuk pengembangan suatu wilayah itu sendiri (Fundeanu, 2015). Selain itu, keberadaan infrastruktur juga menjadi penentu untuk pengembangan suatu wilayah, terutama soal investasi yang akan masuk pada daerah tersebut (Alecsandru \& Raluca, 2015).

Provinsi Bengkulu merupakan salah satu wilayah pesisir yang ada di Indonesia yang memiliki beragam potensi seperti perikanan laut, pariwisata bahari, hutan mangrove dan budidaya tambak (Masydzulhak, 2007). Sejauh ini, pengembangan ekonomi wilayah pesisir provinsi Bengkulu terfokus pada pengelolaan hasil perikanan laut yang ditangkap oleh nelayan yang mendiamin wilayah sekitar pantai. Selain ikan, ada juga tanaman pohon kelapa yang menjadi komoditi unggulan yang diolah menjadi gula kelapa, kelapa parut dan santan secara tradisonal (Bonodikun et al., 2015). Selain itu potensi lainnya yaitu ekosistem hutan mangrove, ekosistem terumbu karang, komunitas padang lamun dan rumput laut, bahanbahan pertambangan dan energi, parawisata, transportasi laut dan pemukiman (Bapeda, 2017).

Upaya strategis untuk memberdayakan dan mengembangkan sumber daya wilayah pesisir dapat dilakukan melalui program pendidikan kewirausahaan yang dilakukan diperguruan tinggi. Melalui kewirausahaan, mahasiswa dapat dilatih untuk dapat melakukan transfer pengetahuan yang ada di masyarakat, tujuannya untuk memperbaiki persoalan ketenagakerjaan ditengah kondisi ekonomi yang tidak menentu (Jaime et al., 2017).

Pendidikan Kewirausahaan merupakan salah satu hal yang sangat dibutuhkan dewasa ini, mengingat jumlah pengangguran di Indonesia yang cukup besar dan menjadi masalah utama bidang perekonomian di Negara Indonesia. Berdasarkan data statistik, jumlah pengangguran di Indonesia per September 2019 tercatat sebesar 9,22 \% atau 24,79 juta orang (BPS, 2020). Dari jumlah tersebut, setidaknya terdapat 5,92\% pengangguran berasal dari lulusan perguruan tinggi (BPS, 2019) yang angkanya terus meningkat sejak tahun 2016 hingga 2018. Hal ini diakibatkan lulusan perguruan tinggi lebih memilih mencari pekerjaan (joob seeker) dibandingkan menciptakan lapangan kerja (job creator) (Nurhayati et al., 2020).

Pembelajaran kewirausahaan pada perguruan tinggi di Indonesia telah dilaksanakan sejak tahun 1997 yang kemudian menjadi program utama Dirjen Pendidikan Tinggi Kemdikbud RI sejak Tahun 2009 (Mudjiarto, 2016), nyatanya belum mampu menumbuhkan minat lulusan perguruan tinggi menciptakan lapangan pekerjaan (job creator) dan menunggu mendapatkan pekerjaan yang cukup lama (Susilaningsih, 2015). Untuk itu perlu suatu inovasi 
pembelajaran yang mampu mengarahkan lulusan perguruan tinggi memiliki kemampuan, keahlian, sikap tanggungjawab, membangun kerjasama tim maupun mengembangkan kemandirian dan mengembangkan usaha melalui kegiatan yang kreatif dalam bidang ilmu yang ditekuni.

Menurut pengertian, kewirausahaan sendiri berarti seseorang yang senantiasa bekerja keras dan pantang menyerah dengan menciptakan bisnis baru dengan mengambil bisnis baru sesuai dengan kunggulan yang dimiliki demi mencapai keuntungan (Scarborough \& Zimmerer, 2009). Misalnya, seorang guru, dapat menghasilkan media pembelajaran yang guru lainnya tidak membuatnya. Dalam pengertian lain, wirausaha merupakan inovator (Klerk \& Kruger, 2002) yang berasal dari perilaku, kompetensi dan kerterampilan yang dimiliki oleh seseorang.

Dari dua pengertian di atas, kewirausahaan tidak melulu selalu dianggap sebagai suatu tindakan mendirikan dan mengelola usaha untuk memperoleh keuntungan. (Susilaningsih, 2015) menyatakan bahwa kewirausahaan merupakan kemampuan mengelola bakat dan potensi yang dimiliki oleh seseorang untuk menciptakan inovasi baru untuk menghasilkan suatu produk baru yang memiliki nilai yang menunjang keberhasilan yang ditekuni.

Salah satu minat seseorang mempelajari kewirausahaan adalah ketersediaan media pembelajaran yang digunakan (Fradani \& Astuti, 2020). Salah satu media pembelajaran yang dapat dimanfaatkan dalam pembelajaran pendidikan kewirausahaan yaitu modul (Puspitasari, 2019). Dengan adanya modul ini diharapkan peserta didik memiliki pengetahuan yang utuh terhadap materi kewirausahaan yang dipelajari, karena pembelajaran sistem modul dilaksanakan secara bertahap, sebab peserta didik harus menyelesaikan kompetensi sebelumnya untuk bisa melanjutkan pada pembelajaran pada kompetensi berikutnya (Rahayu \& Sudarmiatin, 2010). Pemanfaatan modul dalam pembelajaran dapat digunakan peserta didik belajar secara mandiri (S.Sirate \& Ramadhana, 2017). Kemandirian belajar ini merupakan salah satu dari aspek - aspek yang dibutuhkan dalam pelatihan kewirausahaan (Luca et al., 2012)

Universitas Bengkulu sendiri telah menerapkan Kewirausahaan menjadi mata kuliah wajib universitas dengan beban 3 sks. Kenyataannya, jumlah angka mahasiswa yang memiliki kemampuan berwirausaha tergolong rendah, hal ini dikarenakan kurikulum yang dikembangkan kurang mengaitkan potensi lokal sebagai sumber belajar, khususnya wilayah pesisir Provinsi Bengkulu. Modul Kewirausahaan yang selama ini digunakan dalam perkuliahan hanya berisi materi yang masih bersifat umum dan belum mendekatkan mahasiswa dengan lingkungan terdekatnya, sehingga terkesan menitik beratkan pada pengetahuan umum dan menjauhkan mahasiswa dari lingkungan terdekatnya seperti potensi lokal yang menjadi keunggulan di daerahnya. Melalui potensi lokal yang ada di daerahnya, peserta didik dapat diajak untuk melakukan pengamatan, eksplorasi dan mengidentifikasi ekosistem yang ada di daerahnya sebagai materi pembelajaran (Situmorang, 2016) (Rosnawati \& Kaharudin, 2020).

Mata kuliah kewirausahaan di Universitas Bengkulu hendaknya diarahkan pada upaya mengembangkan kompetensi, sikap dan keterampilan sebagai wirausaha yang mampu mengatasi persoalan ekonomi di wilayah pesisir Provinsi Bengkulu. Sebagaimana dinyatakan Fernández-Nogueira et al., (2018) Keberhasilan pendidikan kewirausahaan diperguruan tinggi salah satunya adalah adanya kurikulum kewirausahaan yang melibatkan pemangku kepentingan serta adanya penelitian kolaboratif/kontrak kerja sama. Dengan demikian, kondisi ekonomi masyarakat dapat ditingkat melalui perilaku yang inovatif untuk 
menggerakkan diri sendiri dan orang lain dalam menciptakan dan mengembangkan produk yang bernilai ekonomis. Mengingat, wilayah Provinsi Bengkulu memiliki banyak potensipotensi yang belum di manfaatkan secara maksimal, antara lain sebagai tujuan destinasi wisata rekreatif pantai, diversifikasi olahan produk hasil perikanan tangkap, juga wisata bahari lainnya.

Permasalahan pembelajaran pada mata kuliah kewirausahaan di atas perlu segera diatasi, jika tidak segera dilakukan maka capaian pembelajaran dan tujuan pendidikan kewirausahaan di Universitas Bengkulu tidak akan tercapai secara maksimal. Salah satu upaya yang dilakukan adalah dengan mengembangkan modul pembelajaran kewirausahaan. Hasil penelitian (Harta et al., 2014) menunjukkan bahwa pembelajaran dengan menggunakan modul dapat meningkatkan minat siswa untuk belajar dibandingkan siswa yang belajar tidak dengan menggunakan modul. Modul pembelajaran juga dapat dimanfaatkan untuk siswa dengan gaya belajar visual, siswa aktif dan siswa yang reflektif (Alias \& Siraj, 2012).

Dalam penelitian ini, modul kewirausahaan yang dikembangkan dilakukan dengan memasukkan potensi ekonomi wilayah pesisir Provinsi Bengkulu ini, yang tujuannya dapat membantu mahasiswa untuk memiliki inovasi dan kreativitas dalam menciptakan peluang usaha untuk meningkatkan ekonomi masyarakat wilayah pesisir Provinsi Bengkulu. Salah satu tujuannya untuk mengurangi angka pengangguran dan kemiskinan yang ada di wilayah ini pada khususnya. Sebagaimana (Wagiran, 2012) menyatakan bahwa kearifan lokal dapat diterapkan pada mata pelajaran, dapat pula menjadi mata pelajaran khusus atau diimplementasikan dalam budaya/ iklim sekolah, kepemimpinan, dan manajemen sekolah, maupun hubungan sinergis dengan masyarakat. selain itu juga dapat menjadi promosi pembelajaran dan pengajaran yang ada masyarakat (Pornpimon et al., 2014)

Dari uraian latar belakang di atas, tujuan penelitian dan pengembangan ini mendeskripsikan materi kewirausahaan yang disajikan dalam modul kewirausahaan berorientasi pengembangan ekonomi wilayah pesisir Bengkulu, dan untuk mengetahui kelayakan modul kewirausahaan berorientasi pengembangan ekonomi wilayah pesisir Bengkulu yang ditinjau dari kevalidan, kemenarikan dan kepraktisan.

\section{Metode Penelitian}

Model penelitian dan pengembangan yang digunakan dalam penelitian ini yaitu Model Borg \& Gall. Pertimbangan yang mendasari penggunaan model pengembangan ini adalah: (1) model pengembangan ini diawali terlebih dahulu oleh pengukuran kebutuhan, (2) model pengembangan ini memiliki tahapan-tahapan yang rinci dan sesuai untuk mengembangkan suatu produk tertentu untuk menjawab masalah-masalah dalam pembelajaran serta, (3) karakteristik setiap langkah-langkahnya yang langsung mencerminkan pada pengembangan suatu produk, cerminan pada pengembangan. Model Borg \& Gall sendiri memiliki 10 langkah yang harus ditempuh, namun dalam penelitian ini langkah - langkah tersebut disederhanakan berdasarkan model penelitian Cunningham, menjadi enam langkah. Prosedur penelitian dan pengembangan yang akan ditempuh berdasarkan langkah-langkah model Borg \& Gall dapat dilihat pada gambar di bawah ini. 


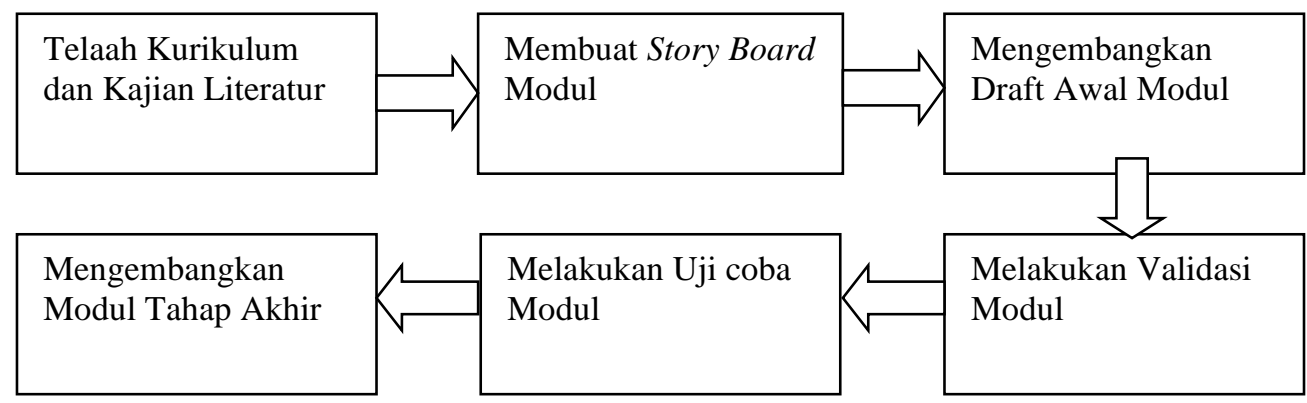

Gambar 1. Proses Penelitian dan Pengembangan Modul Kewirausahaan

Subjek ujicoba dalam penelitian ini melibatkan dua orang ahli, yaitu ahli teknologi pendidikan dan ahli bahasa untuk memvalidasi modul yang dikembangkan. Ahli teknologi pendidikan yang dilibatkan telah memiliki pengalaman dalam bidang penelitian dan pengajaran dalam pengembangan produk pembelajaran dan memiliki latar belakang pendidikan Doktor Teknologi Pendidikan, sedangkan ahli materi yang dilibatkan memiliki pengalaman dalam penelitian dan pengajaran kewirausahaan di perguruan tinggi dan memiliki latar belakang pendidikan Doktor Ilmu Ekonomi.

Pada tahap uji coba lapangan melibatkan mahasiswa Prodi Pendidikan Guru Sekolah Dasar berjumlah 40 orang yang sedang menempuh mata kuliah Kewirausahaan. Tujuannya untuk mendapatkan respon sebagai pengguna terhadap modul kewirausahaan yang telah dikembangkan. Aspek yang diukur dalam tahap ini meliputi ketercapaian capaian pembelajaran mata kuliah, ketertarikan pada materi yang dipelajari, kebahasaan, dan kelayakan materi yang disajikan.

Instrumen pengumpulan data yang digunakan dalam penelitian ini antara lain angket validasi dan angket tanggapan pengguna. Analisis data yang digunakan dalam penelitian ini menggunakan analisis diskriptif yakni analisis kuantitatif adalah data yang diperoleh melalui angket validasi, angket responden dan angket pengguna. Data dikelompokkan dalam bentuk persentase. Analisis deskriptif kuantitatif akan dianalisis dengan deskriptif presentase, dengan rumus (Akbar \& Sriwiyana, 2011):

$$
\begin{array}{ll}
\qquad V=\frac{T S E V}{S-\max } \times 100 \% \\
\text { Keterangan: } \\
\text { V } & =\text { Validitas } \\
\text { TSEV } & =\text { Total Skor Empirik Validator } \\
\text { S-max } & =\text { Skor maksimal yang diharapkan }
\end{array}
$$

Selanjutnya diberikan penafsiran dan pengambilan keputusan tentang kelayakan produk pengembangan dengan menggunakan konversi tingkat pencapaian dengan skala Likert (Riduwan, 2010) yang dinyatakan pada tabel di bawah ini. 
Tabel 1. Konversi Tingkat Kelayakan Produk

\begin{tabular}{ccc}
\hline Tingkat & Kualifikasi & Keterangan \\
\hline Pencapaian & Sangat layak/Sangat & Daik \\
$81 \%-100 \%$ & Layak/ Baik digunakan tanpa revisi \\
$61 \%-80 \%$ & Dapat digunakan dengan revisi \\
$41 \%-60 \%$ & Cukup layak/ Baik & Dapat digunakan dengan revisi \\
$21 \%-40 \%$ & Kurang layak/ & Tidak dapat digunakan \\
$0 \%-20 \%$ & Sangat kurang baik layak/ & Terlarang untuk digunakan \\
\hline
\end{tabular}

Sumber: (Riduwan, 2010)

\section{Hasil dan Pembahasan}

Pengembangan modul kewirausahaan berorientasi pengembangan ekonomi wilayah pesisir Bengkulu dilakukan dengan meninjau Capaian Pembelajaran (CPL) yang tersedia pada Buku Kurikulum Prodi Pendidikan Guru Sekolah Dasar Universitas Bengkulu. Setelah CPL ditetapkan langkah berikutnya mengembangkan CPL-mata kuliah dan menetapkan materi perkuliahan. CPL yang dikembangkan dalam mata kuliah kewirausahaan tersebut yaitu:

Tabel 2. Capaian Pembelajaran Mata Kuliah Kewiirausahaan

\begin{tabular}{clll}
\hline No. & Aspek Kompetensi & Capaian Pembelajaran \\
\hline 1 & Sikap & a) & $\begin{array}{l}\text { Menunjukkan sikap bertanggung jawab atas pekerjaan di } \\
\text { bidang keahliannya secara mandiri. }\end{array}$ \\
& & b) $\begin{array}{l}\text { Menginternalisasi semangat kemandirian, kejuangan, dan } \\
\text { kewirausahaan. }\end{array}$ \\
& & Menguasai konsep dasar dan prosedur penelitian yang dapat \\
& memecahkan permasalahan pembelajaran di sekolah dasar.
\end{tabular}
Sumber: Buku Kurikulum Prodi PGSD Universitas Bengkulu (PGSD, 2015)

Materi perkuliahan yang disajikan dalam modul kewirausahaan ini, yaitu: (1) Apa itu kewirausahaan sosial?; (2) Kisah Sukses Berwirausaha Sosial; (3) Memanfaatkan potensi lokal sebagai ide bisnis; (4) Mengenal Potensi Ekonomi Pesisir Bengkulu; (5) Pemberdayaan masyarakat sebagai modal bisnis kewirausahaan social; (6) Mengidentifikasi ide dan peluang usaha wirausaha social; (7) Sistem produksi; (8) Menghitung titik impas; (9) Merancang media promosi bisnis; (10) Teknik pemasaran dan diversifikasi produk; dan (11) Merancang proposal bisnis kewirausahaan sosial. Setelah tahapan analisis kurikulum dilakukan, langkah selanjutnya adalah mengumpulkan literatur yang sesuai dengan materi yang telah ditetapkan, baik berupa buku teks maupun artikel jurnal yang relevan. 
Materi pada modul ini diarahkan pada pengembangan kompetensi kewirausahaan sosial yang akhir-akhir ini sedang menjadi trendsetter bagi calon wirausahawan terutama dikalangan generasi millenial, seperti kitabisa.com, du'anyam, Tanihub, dan lain-lain. Kewirausahaan sosial merupakan sebuah gerakan sosial yang diusahakan dengan upayaupaya menemukan peluang dan mengolahnya dengan inovasi dan proses belajar yang tiada henti serta kesiapan untuk bertindak tanpa dukungan sumber daya yang memadai (Wibowo \& Nulhaqim, 2015). (Rahadi \& Zanial, 2014) menyatakan wirausaha sosial dapat disebut sebagai individu yang visioner yang mampu memberikan solusi kreatif untuk memecahkan beberapa permasalahan sosial yang terjadi di sekitar kita.

Dalam penelitian ini, kewirausahaan sosial dianggap mampu menjembatani kemampuan kewirausahaan yang selama ini dianggap sebagai sebuah aktivitas yang sulit dilakukan, mengingat waktu yang dibutuhkan untuk mengelola kegiatan usaha tersebut lebih banyak dibandingkan dengan waktu menyelesaikan kegiatan akademik di kampus. Melalui model kewirausahaan sosial ini, mahasiswa diarahkan agar mampu bekerja sama dengan kelompok masyarakat dalam berwirausaha, sehingga waktu yang digunakan oleh mahasiswa untuk menjalankan wirausaha relatif sedikit. Disamping itu, model kewirausahaan ini juga diharapkan mampu menjadi salah satu upaya memutus mata rantai kemiskinan yang ada pada kelompok masyarakat wilayah pesisir Provinsi Bengkulu.

Keragaman potensi alam wilayah pesisir bengkulu yang dikembangkan sebagai materi pembelajaran kewirausahaan dianggap penting, mengingat garis pantai dan laut Provinsi Bengkulu yang begitu panjang, ada banyak keragaman potensi ekonomi yang dapat dikembangkan. Sejauh ini, pengembangan ekonomi wilayah pesisir provinsi Bengkulu terfokus pada pengelolaan hasil perikanan laut yang ditangkap oleh nelayan yang mendiamin wilayah sekitar pantai. Selain ikan, ada juga tanaman pohon kelapa yang menjadi komoditi unggulan yang diolah menjadi gula kelapa, kelapa parut dan santan secara tradisonal (Bonodikun et al., 2015). Selain itu potensi lainnya yaitu ekosistem hutan mangrove, ekosistem terumbu karang, komunitas padang lamun dan rumput laut, bahan-bahan pertambangan dan energi, parawisata, transportasi laut dan pemukiman (Bapeda, 2017).

Salah satu permasalahan dalam pengembangan ekonomi wilayah pesisir di Provinsi Bengkulu adalah kurangnya keterlibatan masyarakat dalam pengembangannya. Misalnya saja, pengembangan kawasan wisata kampung nelayan yang inisiatifnya berasal dari pemerintah setempat, sehingga kemanfaatannya kurang dapat dinikmati oleh masyarakat yang bermukim disana dan tidak mampu memberikan kontribusi dalam pengembangan wilayah (Ismariandi et al., 2010). Dengan demikian, dapat dikatakan bahwa usaha pemerintah tersebut hanya sekedar mengejar target kinerja organisasi perangkat daerah untuk mengahabiskan anggaran pemerintah.

Dalam dalam modul yang dikembangkan, kewirausahaan yang dapat dikembangkan sesuai dengan potensi ekonomi wilayah pesisir Provinsi Bengkulu, diantaranya yaitu:

1) Pengembangan industri ekonomi kreatif, dalam modul pembelajaran kewirausahaan yang akan dikembangkan, diarahkan untuk penciptaan inovasi dan kreatifitas kegiatan ekonomi yang mampu melibatkan masyarakat secara partisipatif kolaboratif yang saling menguntungkan. Kegiatan pengembangan ekonomi wilayah pesisir Bengkulu dapat dilakukan salah satunya dengan mengembangkan industri ekonomi kreatif. Salah satu ide yang dapat dikembangkan dalam menumbuhkan industri ekonomi kreatif yaitu subsektor industri kreatif kerajinan. Hal ini disebabkan ekonomi kreatif merupakan sumber ekonomi baru dalam perekonomian nasional (Amir, 2017). Hasil penelitian (Papilaya et al., 2018) 
menyebutkan kerajinan yang biasanya dibuat dengan memanfaatkan sumberdaya pesisir antara lain, kulit kerang mutiara dibuat menjadi bros, kaligrafi serta lukisan. Kerangkerangan dan jenis siput-siputan dapat dibuat menjadi gelang, kalung, anting-anting, tempat tissue, dan cermin. Kelapa dapat dibuat menjadi tempat permen, vas bunga, asbak dan lain-lain. Pandan pantai, bintangur dan aneka tumbuhan pantai lainnya dapat dibuat menjadi bunga dan pajangan dinding. Pasir dibuat menjadi tempat tissue, jam dinding, vas bunga dan lain-lain.

2) Variasi olahan hasil tangkapan laut yang bernilai ekonomis tinggi. Berdasarkan data Kementerian Kelautan dan Perikanan pada tahun 2018 olahan produk ikan yang dikembangkan di Provinsi Bengkulu diantaranya kerupuk ikan, ikan asap, bakso ikan, ikan asin, pempek ikan, nugget, abon ikan. Namun usaha ini belum maksimal karena permasalahan yang terjadi sistem pemasaran yang belum dilakukan secara profesional. Modul pembelajaran kewirausahan akan diarahkan untuk pengelolaan sistem pemasaran yang menggunakan teknologi informasi.

3) Pengembangan daerah wisata baru yang dikelola secara profesional. Mahasiswa diarahkan untuk mampu menciptakan pengembangan daerah wisata baru. Tempat wisata ini bisa didesain dengan konsep pengembangan wisata terpadu, maksudnya mengembangkan konsep pariwisata yang menggabungkan beberapa konsep pengembangan. Misalnya dengan wisata edukasi berbasis ekosistem pantai, seperti taman pintar dan lain sebagainya.

Setelah draft awal produk pengembangan diperoleh, tahap berikutnya adalah melakukan uji validasi ahli teknologi pendidikan dan ahli materi. Uji validasi dilakukan dengan memberikan angket validasi kepada kedua ahli tersebut secara bersamaan. Data yang diperoleh dari hasil uji validasi ini berupa data kuantitatif kelayakan modul serta saran dan komentar dari ahli untuk selanjutnya dilakukan revisi pada modul yang dikembangkan. Berikut ini disajikan hasil uji validasi ahli pada Tabel 2 dan Tabel 3 di bawah ini.

Tabel 3. Deskripsi Data Validasi Modul oleh Ahli Teknologi Pendidikan

\begin{tabular}{clcc}
\hline No. & \multicolumn{1}{c}{ Aspek Penilaian } & Skor Perolehan & Kategori \\
\hline 1 & $\begin{array}{l}\text { Kesesuaian modul dengan sasaran } \\
\text { pengguna }\end{array}$ & $82 \%$ & Sangat Layak \\
2 & $\begin{array}{l}\text { Ketepatan fungsi dan manfaat } \\
\text { modul }\end{array}$ & $79 \%$ & Layak \\
3 & $\begin{array}{l}\text { Kesesuaian desain media dan } \\
\text { keterbacaan pada modul } \\
4\end{array}$ & $58 \%$ & Cukup Layak \\
\hline
\end{tabular}

Dari data tabel 3. Di atas dapat dilihat bahwa secara keseluruhan hasil validasi ahli teknologi pendidikan telah menyatakan bahwa modul pembelajaran yang telah dikembangkan layak untuk digunakan. Namun demikian pada bagian penilaian aspek kesesuaian desain media dan keterbacaan pada modul masih mendapatkan skor terendah sebesar $58 \%$, hal ini terjadi karena terdapat kalimat dalam modul yang tidak disesuaikan dengan bahasa peserta didik, seperti misalnya istilah entrepreneur yang seharusnya dapat diganti dengan istilah dalam bahasa indonesia, yaitu kewirausahaan. 
Tabel 4. Deskripsi Data Validasi Modul oleh Ahli Materi

\begin{tabular}{|c|c|c|c|}
\hline No. & Aspek Penilaian & Skor Perolehan & Kategori \\
\hline 1 & $\begin{array}{l}\text { Kecukupan dan akurasi materi } \\
\text { yang disajikan. }\end{array}$ & $77,5 \%$ & Layak \\
\hline 2 & $\begin{array}{l}\text { Novelty pada informasi materi } \\
\text { yang disajikan. }\end{array}$ & $86,25 \%$ & Sangat layak \\
\hline 3 & Aspek Kontekstual pada modul & $82,5 \%$ & Sangat layak \\
\hline 4 & Aspek kebahasaan modul & $72,5 \%$ & Layak \\
\hline
\end{tabular}

Dari tabel 4. Di atas, dapat diketahui bahwa secara umum modul kewirausahaan telah layak digunakan. Catatan berupa saran dan komentar dari ahli teknologi pendidikan dan ahli materi akan dijadikan sebagai acuan untuk dilakukan revisi pada modul agar dapat dilanjutkan pada tahap berikutnya.

Setelah tahap revisi modul dari hasil uji validasi ahli, langkah selanjutnya adalah uji coba lapangan. Sebelum diterapkan pada kelompok yang besar, terlebih dahulu modul di uji cobakan pada 3 orang peserta didik. Pemilihan peserta didik dalam uji coba ini didasarkan pada kriteria tingkat kemampuan peserta didik tinggi, sedang dan rendah. Kemampuan ini dapat dilihat dari perolehan Indeks Prestasi yang diperoleh peserta didik pada semester sebelumnya.

Tahap uji coba kelompok kecil dilakukan untuk mendapatkan kriteria kemenarikan terhadap modul yang dikembangkan. Hasil uji coba modul pada kelompok kecil dapat dilihat pada Tabel 4. Di bawah ini.

Tabel 4.

Deskripsi Data Hasil Penilaian Kelompok Kecil Terhadap Modul

\begin{tabular}{|c|l|c|c|}
\hline No. & \multicolumn{1}{|c|}{ Aspek Penilaian } & $\begin{array}{c}\text { Presentase Skor } \\
\text { Perolehan }\end{array}$ & Kategori \\
\hline 1 & $\begin{array}{l}\text { Tinjauan terhadap fungsi dan } \\
\text { manfaat modul kewirausahaan }\end{array}$ & $82,9 \%$ & Sangat baik \\
\hline 2 & $\begin{array}{l}\text { Kemenarikan desain dan tingkat } \\
\text { keterbacaan }\end{array}$ & $74,3 \%$ & Baik \\
\hline 3 & Kelengkapan sajian pada modul & $85,7 \%$ & Sangat baik \\
\hline
\end{tabular}

Dari tabel 4 di atas dapat disimpulkan bahwa, modul kewirausahaan yang dikembangkan memperoleh respon yang sangat baik. Catatan berupa saran dan komentar dalam angket kemenarikan yang diberikan kepada subjek uji coba lapangan dijadikan sebagai bahan untuk melakukan revisi modul. Kemenarikan modul kewirausahaan ini selaras dengan hasil penelitian (Safitri et al., 2018) modul pembelajaran berbasis kopi yang dikembangkan mendapatkan respon yang sangat baik dari siswa. Kemenarikan modul kewirausahaan ini juga disebabkan karena materi yang disajikan dalam modul berbasis kearifan lokal yang ada di lingkungan sekitar peserta didik. Melalui pemanfaatan bahan ajar berbasis nilai budaya lokal mengisi ketersediaan dan menambah keragaman sumber belajar pada pembelajaran (Setiono, 2016).

Setelah dilakukan tahap revisi, selanjutnya modul diujicobakan pada tahap yang lebih luas, yaitu seluruh mahasiswa kelas $4 \mathrm{~A}$ yang mengontrak mata kuliah kewirausahaan. Tujuannya yaitu untuk mendapatkan hasil respon mahasiswa terhadap kepraktisan modul pembelajaran yang telah direvisi setelah tahap uji kelompok kecil. Berikut ini disajikan hasil uji kepraktisan modul kewirausahaan pada tabel 5 di bawah ini. 
Tabel 5. Deskripsi data hasil uji coba kepraktisan terhadap modul

\begin{tabular}{|c|c|c|c|}
\hline No. & Aspek Penilaian & $\begin{array}{c}\text { Presentase Skor } \\
\text { Perolehan }\end{array}$ & Kategori \\
\hline 1 & Ketercapaian tujuan pembelajaran & $84,62 \%$ & Sangat baik \\
\hline 2 & Ketertarikan mempelajari modul & $85,26 \%$ & Sangat baik \\
\hline 3 & Kesesuaian materi yang disajikan & $76,92 \%$ & Baik \\
\hline 4 & Kemenarikan tampilan modul & $88,6 \%$ & Sangat Baik \\
\hline
\end{tabular}

Dari tabel 5 di atas, dari hasil analisis kepraktisan melalui uji lapangan dapat disimpulkan bahwa modul kewirausahaan layak untuk digunakan. Kepraktisan modul kewirausahaan ini dapat dimaknai sebagai kemudahan peserta didik menggunakan modul dalam proses pembelajaran baik yang dilakukan bersama dosen maupun dilakukan sendiri. Hal ini sesuai dengan pendapat (Alfiriani \& Hutabri, 2017) yang mengatakan kepraktisan mengacu pada kondisi modul pembelajaran yang dikembangkan dapat dengan mudah digunakan oleh peserta didik sehingga pembelajaran yang dilakukan bermakna, menarik, menyenangkan, dan berguna bagi kehidupan peserta didik, serta dapat meningkatkan kreativitas mereka dalam belajar dan memiliki drajat kefektifan terhadap hasil belajar peserta didik.

Tahap terakhir dalam proses penelitian dan pengembangan ini adalah melakukan revisi setelah uji lapangan dilakukan. Setelah direvisi, maka modul kewirausahaan yang dikembangkan telah layak untuk digunakan dan disebarluaskan pada lingkungan yang lebih luas lagi. Dengan adanya modul kewirausahaan berorientasi pengembangan ekonomi wilayah pesisir Bengkulu ini dapat menambah variasi sumber-sumber belajar kewirausahaan di Universitas Bengkulu. Sebagaimana (Xu et al., 2019) menyatakan dalam penelitiannya, variasi dalam isi modul mampu meningkatkan pencapaian tujuan pengajaran modul secara signifikan. Modul kewirausahaan yang telah dikembangkan juga mampu sebagai bahan ajar yang memadai untuk digunakan dalam proses pembelajaran kewirausahaan serta mampu merangsang mahasiswa untuk berpikir memahami konsep-konsep kewirausahaan, hal ini sesuai dengan hasil penelitian (Serena et al., 2018).

\section{Kesimpulan}

Hasil penelitian ini menunjukkan hasil uji validasi dari para ahli dan uji coba lapangan terhadap modul kewirausahaan berorientasi pengembangan ekonomi wilayah pesisir Bengkulu dimana semua aspek menunjukan media pembelajaran yang telah dibuat ini layak untuk digunakan dalam kegiatan pembelajaran di Sekolah. Adanya materi pembelajaran yang berbasis lokal di Bengkulu menarik minat mahasiswa untuk belajar kewirausahaan. Rekomendasi yang diberikan berdasarkan hasil yang diperoleh adalah dengan menambah materi dalam modul kewirausahaan ini sehingga tidak hanya tentang materi sikap dan perilaku wirausaha saja, dan tidak hanya dibuat dalam bentuk modul cetak tetapi juga dibuat modul digital sehingga peserta didik bisa membaca modul kewirausahaan tersebut darimana saja dengan bantuan smartphone yang mereka miliki. 


\section{Ucapan Terima Kasih}

Ucapan terima kasih, Peneliti sampaikan kepada Lembaga Penelitian dan Pengabdian Masyarakat Universitas Universitas Bengkulu yang telah mendanai penelitian ini melalui skema Penelitian Pembinaan Tahun Anggaran 2020.

\section{Daftar Pustaka}

Akbar, S., \& Sriwiyana, H. (2011). Pengembangan kurikulum dan pembelajaran ilmu pengetahuan sosial. Malang: Cipta Media.

Alecsandru, S. V., \& Raluca, D. A. (2015). A Regional Level Hierarchy of the Main Foreign Direct Investments' Determinants-Empirical Study, the Case of Romanian Manufacturing Sector. Procedia - Social and Behavioral Sciences, 181, 321-330. https://doi.org/10.1016/j.sbspro.2015.04.894

Alfiriani, A., \& Hutabri, E. (2017). Practicality And Effectiviness Of Bilingual ComputerBased Learning Module. Jurnal Kependidikan: Penelitian Inovasi Pembelajaran, 1(1), 12-23. https://doi.org/10.21831/jk.v1i1.10896

Alias, N., \& Siraj, S. (2012). Effectiveness of Isman Instructional Design Model in Developing Physics Module based on Learning Style and Appropriate Technology. Procedia - Social and Behavioral Sciences, 64(4), 12-17. https://doi.org/10.1016/j.sbspro.2012.11.002

Amir, M. (2017). Kebijakan Ekonomi Kreatif Berbasis Industri Kerajinan Unggulan Dalam Upaya Mengangkat Kearifan Lokal Kabupaten Tuban. Cakrawala, 11(2), 157-169. https://doi.org/https://doi.org/10.32781/cakrawala.v11i2.16

Bapeda. (2017). Rencana Aksi Daerah Pengembangan Ekonomi Kemaritiman Di Provinsi Bengkulu Tahun 2017. Badan Perencanaan, Penelitian Dan Pengembangan Daerah Provinsi Bengkulu.

Bonodikun, Asriani, P. S., \& Yuliarti, E. (2015). Kajian Agroindustri Unggulan Wilayah Pesisir Kota Bengkulu. AGRISEP, 14(1), 79-84.

BPS. (2019). Badan Pusat Statistik. https://www.bps.go.id/publication/2019/09/26/c90ef44501d430ddb065bec5/statistikindonesia-dalam-infografis-2019.html

BPS. (2020). Badan Pusat Statistik. https://www.bps.go.id/publication/2020/04/29/e9011b3155d45d70823c141f/statistikindonesia-2020.html

Fernández-Nogueira, D., Arruti, A., Markuerkiaga, L., \& Sáenz, N. (2018). The entrepreneurial university: A selection of good practices. Journal of Entrepreneurship Education, 21(Special Issue).

Fradani, A. C., \& Astuti, R. P. F. (2020). Pengembangan Media Pembelajaran Kewirausahaan Berbasis Komik Untuk Siswa Di Smk Negeri 1 Bojonegoro. Jurnal $\begin{array}{lllll}\text { Ekonomi Pendidikan Dan } & \text { Kewirausahaan, }\end{array}$ https://doi.org/10.26740/jepk.v8n2.p111-120

Fundeanu, D. D. (2015). Innovative Regional Cluster, Model of Tourism Development. Procedia Economics and Finance, 23, 744-749. https://doi.org/10.1016/s22125671(15)00501-8

Harta, I., Tenggara, S., \& Kartasura, P. (2014). Pengembangan Modul Pembelajaran untuk Meningkatkan Pemahaman Konsep dan Minat SMP. Pengembangan Modul Pembelajaran Untuk Meningkatkan Pemahaman Konsep Dan Minat SMP, 9(2), 161-174. https://doi.org/10.21831/pg.v9i2.9077

Ismariandi, R., Setijanti, P., \& Ariastita, P. G. (2010). Konsep Pengembangan kampung Nelayan pasar Bengkulu Sebagai kawasan Wisata. Seminar Nasional Perumahan Pemukiman Dalam Pembangunan Kota, 1-14.

Jaime, M. P., Gómez, A., \& Rueda-armengot, J. M. M. C. (2017). Entrepreneurial Universities Exploring the Academic. January. https://doi.org/10.1007/978-3-319-47949-1 
Klerk, G. J., \& Kruger, S. (2002). The driving force behind entrepreneurship: An exploratory perspective. http://www.kmu.unisg.ch/recontres/bond\%0A2002/F_04_deKlerl.pdf diakses 4 Januari 2021

Leigh, N. G., \& Blakely, E. J. (2016). Planning Local Economic Development | SAGE Publications Inc. Sage Publishing. https://us.sagepub.com/en-us/nam/planning-local-economicdevelopment/book244769\#preview

Luca, M. R., Cazan, A. M., \& Tomulescu, D. (2012). To be or not to be an entrepreneur... Procedia - Social and Behavioral Sciences, 33, 173-177. https://doi.org/10.1016/j.sbspro.2012.01.106

Masydzulhak. (2007). Pengelolaan Sumberdaya Wilayah Pesisir Kota Bengkulu. In Pesisir dan Lautan (Vol. 8, Issue 1, p. 32).

Mudjiarto. (2016). Membangun Karakter Dan Kepribadian Kewirausahaan. Perpustakaan Universitas Esa Unggul, O(0). https://digilib.esaunggul.ac.id/public/UEU-Books-752910_0017.Image.Marked.pdf

Nurhayati, D., Machmud, A., \& Waspada, I. (2020). Technopreneurship Intention: Studi Kasus Pada Mahasiswa Dipengaruhi Entrepreneurial Learning. Jurnal Ekonomi Pendidikan Dan Kewirausahaan, 8(1), 79. https://doi.org/10.26740/jepk.v8n1.p79-92

Papilaya, R. L., Hiariey, J., \& Risakotta, T. (2018). Strategi Pengembangan Industri Kreatif Berbasis Sumberdaya Pesisir Dan Laut Di Kota Ambon. PAPALELE (Jurnal Penelitian Sosial Ekonomi Perikanan Dan Kelautan), 2(1), 33-43. https://doi.org/10.30598/papalele.2018.2.1.33

PGSD. (2015). Buku Kurikulum PGSD Tahun 2015.

Pornpimon, C., Wallapha, A., \& Prayuth, C. (2014). Strategy Challenges the Local Wisdom Applications Sustainability in Schools. Procedia - Social and Behavioral Sciences, 112(Iceepsy 2013), 626-634. https://doi.org/10.1016/j.sbspro.2014.01.1210

Pramono, R. F., \& Sulistyarso, H. (2013). Pengembangan Ekonomi Lokal di Kawasan Perikanan Berdasarkan Preferensi Masyarakat Nelayan Nambangan Kedung Cowek. Jurnal Teknik ITS, 2(2), C203-C206.

Puspitasari, A. D. (2019). Penerapan Media Pembelajaran Fisika Menggunakan Modul Cetak dan Modul Elektronik pada Siswa SMA. Jurnal Pendidikan Fisika, 7(1), 17-25.

Rahadi, D. R., \& Zanial, M. (2014). Implementasi Konsep Kewirausahaan sosial Sebagai Model Pembelajaran di Perguruan Tinggi. Jurnal Matriks, 2.

Rahayu, W. P., \& Sudarmiatin. (2010). Pengembangan modul kewirausahaan di SMK.pdf. Jurnal Ilmu Pendidikan, 17(2), 157-161. http://journal.um.ac.id/index.php/jip/article/download/2634/1362

Riduwan. (2010). Skala pengukuran variabel-variabel penelitian. Bandung: Alfabea. https://opac.perpusnas.go.id/DetailOpac.aspx?id=350661

Rosnawati, V., \& Kaharudin, L. ode. (2020). Pengembangan Ensiklopedia Berbasis Potensi Lokal Yang Terdapat Di Wakatobi Pada Materi Pokok Animalia Invertebrata (Mollusca Dan Echinodermata). JIKAP PGSD: Jurnal Ilmiah Ilmu Kependidikan, 4(1), 84. https://doi.org/10.26858/jkp.v4i1.12055

S.Sirate, S. F., \& Ramadhana, R. (2017). Pengembangan Modul Pembelajaran Berbasis $\begin{array}{llll}\text { Keterampilan } \quad \text { Literasi. Inspiratif } & 316 .\end{array}$ https://doi.org/10.24252/ip.v6i2.5763

Safitri, A. N., Subiki, S., \& Wahyuni, S. (2018). Pengembangan Modul IPA Berbasis Kearifan Lokal Kopi Pada Pokok Bahasan Usaha Dan Energi Di SMP. JURNAL PEMBELAJARAN FISIKA, 7(1), 22. https://doi.org/10.19184/jpf.v7i1.7221

Scarborough, N. M., \& Zimmerer, T. W. (2009). Kewirausahaan dan Manajemen Usaha Kecil $\begin{array}{llll}\text { Buku } 2 \text { (Edisi } 2 \text { Jakarta: Salemba Empat. } & \text {. }\end{array}$ http://library.fis.uny.ac.id/opac/index.php?p=show_detail\&id=5144

Serena, V., Sunaryo, Raihanati, Astra, I. M., \& Juwita, I. (2018). Development of E-Module Based on Problem Based Learning ( PBL ) on Heat and Temperature to Improve Student ' s Science Process Skill. TOJET: The Turkish Online Journal of Educational Technology, 
17(3), 26-36. https://files.eric.ed.gov/fulltext/EJ1184205.pdf

Setiono, P. (2016). Pemanfaatan Nilai Budaya Lokal Tari Topeng Malang sebagai Bahan Ajar untuk Siswa Kelas IV Sekolah Dasar. Jurnal Pendidikan Dan Pembelajaran Anak Sekolah Dasar, 1(2), 115-126. https://jurnal.stkippgritulungagung.ac.id/index.php/pena$\mathrm{sd} /$ article/view/173

Situmorang, R. (2016). Analisis Potensi Lokal Untuk Mengembangkan Bahan Ajar Biologi Di Sma Negeri 2 Wonosari. Jurnal Pendidikan Sains Universitas Muhammadiyah Semarang, 4(1), 51-57. https://doi.org/10.26714/jps.4.1.2016.51-57

Susilaningsih, S. (2015). Pendidikan Kewirausahaan Di Perguruan Tinggi: Pentingkah Untuk Semua Profesi? Jurnal Economia, 11 . https://doi.org/10.21831/economia.v11i1.7748

Wagiran. (2012). Pengembangan Karakter Berbasis Kearifan Lokal Hamemayu Hayuning Bawana (Identifikasi Nilai-nilai Karakter Berbasis Budaya). Jurnal Pendidikan Karakter, 3, 120801. https://doi.org/10.21831/jpk.v0i3.1249

Wibowo, H., \& Nulhaqim, S. A. (2015). Kewirausahaan Sosial (Merevolusi Pola Pikir Menginisiasi Mitra Pembangunan). In Unpad Pers.

Xu, Z., Harzallah, M., Guillet, F., \& Ichise, R. (2019). Modular ontology learning with topic modelling over core ontology. Procedia Computer Science, 159, 562-571. https://doi.org/10.1016/j.procs.2019.09.211 